\title{
Effect of Dietary Inclusion of Cumin Seed (Cuminum cyminum) on Voluntary Feed Intake, Milk Yield, Milk Quality and Udder Health of Dairy Cows
}

\author{
S. Bhargav¹, A.K. Patil', R.K. Jain¹, N. Kurechiya', R. Aich², A.K. Jayraw³
}

10.18805/ajdfr.DR-1792

\begin{abstract}
Background: Plants containing essential oils can be a cost-effective means of improving efficiency of milk production and optimizing milk composition of dairy cows. Cuminum cyminum (green cumin) belongs to the Apiaceae family and is a well-known herbal medicine in Iran. The medicinal properties of cumin may have beneficial effects on milk production. However, very few studies have been reported whereby cumin has been fed to ruminants. Therefore, the present study is design to investigate the effect of cumin supplementation on milk yield, milk quality and udder health of lactating dairy cows.

Methods: Twelve multiparous lactating cows at early stage of lactation was selected and randomly allotted to two equal groups ( $n=6$ ) on the basis of milk yield. In addition to normal routine feeds and fodders, cows in groups T1 was fed cumin seed @ $50 \mathrm{~g} / \mathrm{d} / \mathrm{head}$ for 90 days. Fortnightly body weight was determined on the basis of body measurement of animals. All feed samples was analysed for proximate composition, $\mathrm{Ca}$ and $\mathrm{P}$. The daily milk yield $(\mathrm{kg} / \mathrm{d})$ of individual cows was recorded by weighing. Milk samples were collected after complete milking and thorough mixing for determination of milk composition. Udder health was monitored by MCMT (modified california mastitis test), measuring milk pH and SCC (somatic cell count) at fortnightly intervals.

Result: The results indicated that overall mean body weight, average DMI was statistically $(P>0.05)$ similar in both the groups. The average milk yield $(\mathrm{kg})$ of animals was statically non significant $(P>0.05)$ but numerically $20.64 \%$ higher milk yield was observed in cumin seed supplemented group than control group. There was no effect of cumin supplementation on chemical composition (Fat, TS, SNF, Lactose and Protein) of milk in dairy cows. Overall mean milk pH and somatic cell count (SCC) in both the groups was statically similar but numerically lower in treatment group. The overall mean (\%) of MCMT positive animals was 14.29 and 9.52 in $T_{0}$ (Control) and $T_{1}$ (Treatment) groups, respectively. From the results it can be deduced that the cumin seed (Cuminum cyminum) supplementation improves milk yield by $20.64 \%$. However, it has no effect on composition of milk in dairy cows. Supplementation improved the udder health and found no effect on dry matter intake (DMI) in dairy cows.
\end{abstract}

Key words: Cumin seed, Milk yield, Milk composition, Udder health.

\section{INTRODUCTION}

Beneficial effects of herbs in farm animals may arise from the activation of feed intake and the secretion of digestive secretions, immune stimulation and antibacterial activity. Herbs can also contribute to the nutrient requirements of the animals, stimulate the endocrine system and intermediate nutrient metabolism. Plants containing essential oils can be a cost-effective means of improving efficiency of milk production and optimizing milk composition of dairy cows (Tassoul and Shaver, 2009). Cuminum cyminum (green cumin) belongs to the Apiaceae family and is a well-known herbal medicine in Iran. Herbal medicines and essential oils from cumin have been shown to have medicinal value for treating digestive disorders, toothaches, wounds, hoarseness, epilepsy and jaundice (Muthamma et al., 2008; Moghaddam et al., 2015). Moreover, Bhatt et al. (2009) reported that cumin has galactapoiesis properties and the fruits are used to stimulate breast milk production in Iranian traditional medicine (Hashemian et al., 2013). The medicinal properties of cumin may have beneficial effects on milk production. Due to the above mentioned benefits of cumin
1Department of Animal Nutrition, College of Veterinary Science and Animal Husbandry, Nanaji Deshmukh Veterinary Science University, Mhow-453 441, Madhya Pradesh, India.

2Department of Veterinary Biochemistry, College of Veterinary Science and Animal Husbandry, Nanaji Deshmukh Veterinary Science University, Mhow-453 441, Madhya Pradesh, India.

${ }^{3}$ Department of Veterinary Parasitology, College of Veterinary Science and Animal Husbandry, Mhow-453 441, Madhya Pradesh, India.

Corresponding Author: A.K. Patil, Department of Animal Nutrition, College of Veterinary Science and Animal Husbandry, Nanaji Deshmukh Veterinary Science University, Mhow-453 441, Madhya Pradesh, India. Email: ashokdrpatil@gmail.com

How to cite this article: Bhargav, S., Patil, A.K., Jain, R.K., Kurechiya, N., Aich, R., Jayraw, A.K. (2021). Effect of Dietary Inclusion of Cumin Seed (Cuminum cyminum) on Voluntary Feed Intake, Milk Yield, Milk Quality and Udder Health of Dairy Cows. Asian Journal of Dairy and Food Research. DOI: 10.18805/ ajdfr.DR-1792.

Submitted: 28-07-2021 Accepted: 26-10-2021 Online: 20-12-2021 
feeding and very few studies have been reported whereby cumin has been fed to ruminants. Therefore, the present study is design to investigate the effect of cumin supplementation on milk yield, milk quality and udder health of lactating dairy cows.

\section{MATERIALS AND METHODS}

The experiment was conducted in month of September to December 2019 at Ahilyamata Gaushala, Indore (M.P.). Twelve multiparous lactating cows at early stage of lactation was selected and housed in a separate shed of having provision of both open and close space. Proper health management and sanitation conditions were maintained throughout the experimental period.

Animals were divided into 2 groups of 6 each on the basis of milk yield $(4.72 \mathrm{~kg}$ ) and body weight $(407 \mathrm{~kg}$ ) following randomized block design (RBD). The cow in group $T_{0}$ was not given any supplement (control). In addition to normal routine feeds and fodders, cows in groups $T_{1}$ was given cumin seed @ $50 \mathrm{~g} / \mathrm{d} /$ head for 90 days. All the animals were fed standard seasonally available roughages viz. MP chari, wheat straw and concentrates mixture throughout the study period of 90 days to meet nutrient requirement (ICAR 2013). Chemical composition of the experimental feeds fed to the animals is presented in Table 1 . The milking was performed twice daily at 5 AM and 4 PM and milk yield (MY) was recorded daily at each milking using an electronic digital balance. Fortnightly body weight was determined on the basis of body measurement of animals by using the Shaeffer's formula (Sastry et al., 1982). During experimental period, daily feed offered and residue leftover was recorded to determine voluntary feed intake at fortnightly intervals. All feed samples was analysed for proximate composition as per the standard procedures (AOAC, 2005) and fibre fractions (Van Soest et al., 1991).

Milk fat, protein, solid not fat (SNF), lactose and total solids were analyzed by Electronic Lactoscan (Milk Analyser ISO 9001. 2000 and serial no. 5565). For the analysis, thoroughly mixed milk sample was taken in the bottle and transferred in a clean receptacle provided with lactoscan. Udder health indices; pH (Model pHep-HI 70300), Somatic Cell Count (Dang and Anand, 2007) and MCMT (Sastry, 1978) were measured fortnightly. Economics of feeding was calculated by considering expenditure on feeds and cumin seed and returns from the sale of milk. Data pertaining to feed intake, milk yield, milk composition and udder health were subjected to independent 't' test. All analysis were performed using statistical package SPSS (20.0).

\section{RESULTS AND DISCUSSION \\ Effect of dietary inclusion of cumin seed on voluntary feed intake of dairy cows}

Feeding cumin did not make any significant change in voluntary dry matter intake, but numerically the treatment group consumed more than the control (Table 2). Similar intake of DM is suggestive of no adverse effects of cumin seed on palatability. Similar, to our findings, Morsy et al. (2018) reported that there was no any effect on feed intake by supplementation of cumin seed in Dammascus goats. Patel et al. (2017) was also revealed no effect on feed intake by supplementation of herbal galactogogue. Similarly, Miri et al. (2013) were also recorded that the feeding of cumin seed in lactating goat did not affect the dry matter intake. In contrary to ours finding, some researchers observed variation in dry matter intake by supplementation of cumin seed in dairy cows (Ghafari et al. 2015; Durrani et al. 2007).

\section{Effect of dietary inclusion of cumin seed on milk yield $(\mathrm{kg} / \mathrm{d})$ of dairy cows}

In the present study, there was no significant $(P>0.05)$ change in milk production was observed due to cumin feeding at different fortnights in both the groups (Fig 1), The results revealed that the fortnightly average milk yield $(\mathrm{kg} / \mathrm{d})$ at different fortnights were similar between the experimental groups and did not differ significantly $(P>0.05)$. However, the percentage increased $(P>0.05)$ in milk was $20.64 \%$ in cumin seed supplemented group. In agreement to this, Ghafari et al. (2015) observed that there was an increase in milk yield by supplementation of cumin seed in dairy cows. Morsy et al. (2018) was also revealed that there was increase in milk yield by supplementation of mustard and cumin seed in different groups of Damascus goats. Similarly, Bhatt et al. (2009) also reported that there was higher $(\mathrm{P}<0.05)$ milk yield in herbal preparation (Ruchamax or Payapro) supplemented lactating crossbred cows. Similar

Table 1: Chemical (\% DM basis) composition of feed ingredients.

\begin{tabular}{|c|c|c|c|c|}
\hline Particulars (\%) & Concentrate mixture & MP chari & Wheat straw & Cumin seed \\
\hline Dry matter (DM) & 91.2 & 20.8 & 86.8 & 92.3 \\
\hline Crude protein $(\mathrm{CP})$ & 15.6 & 4.9 & 3.6 & 16.2 \\
\hline Ether extract (EE) & 2.5 & 1.12 & 1.3 & 11.1 \\
\hline Crude fibre (CF) & 9.4 & 34.0 & 38.0 & 39.0 \\
\hline Total ash (TA) & 10.6 & 9.1 & 9.4 & 9.1 \\
\hline Nitrogen free extract (NFE) & 61.9 & 50.8 & 47.7 & 24.6 \\
\hline Neutral detergent fibre (NDF) & 34.4 & 60.6 & 71.3 & 32.8 \\
\hline Acid detergent fibre (ADF) & 10.9 & 31.2 & 48.2 & 20.8 \\
\hline Calcium (Ca) & 1.16 & 0.61 & 0.44 & 1.17 \\
\hline Phosphorus (P) & 0.98 & 0.33 & 0.13 & 0.8 \\
\hline
\end{tabular}


Table 2: Effect of dietary inclusion of cumin seed on dry matter intake, milk yield and milk composition of dairy cows.

\begin{tabular}{lccc}
\hline Fortnights & $\mathrm{T}_{0}$ (control) & $\mathrm{T}_{1}$ (treatment) & Level of significance \\
\hline Avg. DMI $(\mathrm{Kg} / \mathrm{d})$ & $8.68 \pm 0.38$ & $10.40 \pm 0.28$ & 0.36 \\
Avg. BW $(\mathrm{Kg})$ & $407 \pm 28.93$ & $417 \pm 10.07$ & 0.07 \\
Overall mean milk yield $(\mathrm{Kg} / \mathrm{d})$ & $4.31 \pm 0.33$ & $5.20 \pm 0.61$ & 0.43 \\
$\%$ increased in milk yield & - & $20.64 \%$ & \\
Milk composition & & & 0.41 \\
Milk fat $(\%)$ & $4.42 \pm 0.02$ & $4.28 \pm 0.01$ & 0.78 \\
Milk SNF $(\%)$ & $8.24 \pm 0.01$ & $8.27 \pm 0.01$ & 0.30 \\
Milk lactose (\%) & $4.41 \pm 0.02$ & $4.63 \pm 0.02$ & 0.58 \\
Milk protein $(\%)$ & $3.24 \pm 0.03$ & $3.45 \pm 0.02$ & 0.65 \\
Milk total solid $(\%)$ & $12.66 \pm 0.03$ & $12.53 \pm 0.02$ & 0.45 \\
Fat corrected milk $(\mathrm{FCM}) \%$ & $5.40 \pm 0.63$ & 0.31 \\
Solid corrected milk $(\mathrm{Kg} / \mathrm{d})$ & $4.55 \pm 0.35$ & $5.65 \pm 0.68$ & 0.44 \\
Energy corrected milk $(\mathrm{Kg} / \mathrm{d})$ & $4.51 \pm 0.31$ & $7.38 \pm 0.86$ & 0.42 \\
Milk gross energy $(\mathrm{Kcal} / \mathrm{kg})$ & $6.09 \pm 0.48$ & $741.01 \pm 1.28$ & \\
\hline
\end{tabular}

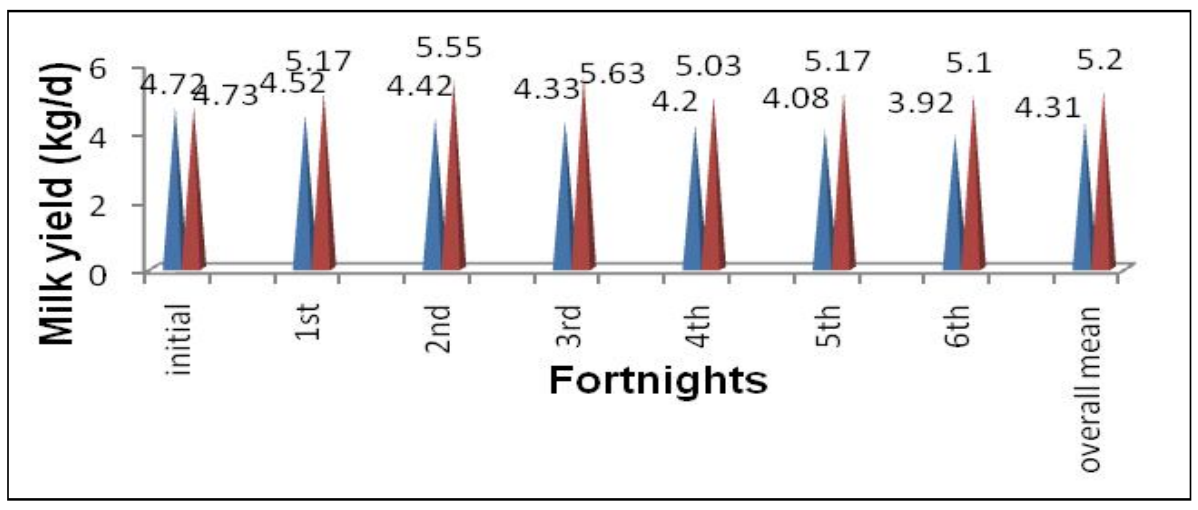

Fig 1: Effect of dietary inclusion of cumin seed on milk yield $(\mathrm{kg} / \mathrm{d})$ of dairy cows.

results were also observed by Patel et al. (2017) and Goswami et al. (2018) in dairy cows. In agreement with present results, Chandra et al. (2017) also observed that there was an increase in milk yield by supplementation of poly-herbal mixture in Murrah buffaloes. Like present experiment findings, many scientists also found that feeding cumin seedand other polyherbal preparation leads to increase in milk production in animals of different species (Mahmoud and Ghoneem (2014); Galbatet al. (2014); Ramesh et al. (2000); Kumar and Kumar (2018) and Gautam et al. (2019). Earlier scientists have found that feeding cumin brings about a significant change in feed utilization and rumen fermentation and for this reason there is an increase in milk production (Morsy et al. 2018). Feeding cumin seeds in the present study also have shown $20.64 \%$ increase in average milk yield in dairy cows, it might be due to galactagogues effect of cumin seed and its effect on ruminal fermentation and feed utilization.

\section{Effect of dietary inclusion of cumin seed on milk composition of dairy cows}

From the results, it may be deduced that the milk composition (Milk fat, SNF, lactose, milk protein, total solid, FCM, SCM, ECM and GE) has not affected by cumin seed supplementation in dairy cows (Table 2). Present findings were akin to that of Chandra et al. (2017) who also observed no significant change in milk protein, lactose and SNF but the values were numerically higher in poly-herbal mixture supplemented groups. Correspondingly, Miri et al. (2013) was also found that the cumin seed extract supplementation had no effect on milk fat, protein and lactose percentage in lactating dairy cows. In contrast to present results, Galbat et al. (2014) observed that feeding cumin rich feed additives significantly $(P<0.05)$ increases milk protein, total solid and SNF in Egyptian dairy goats. Some scientists have also found that feeding herbal feed additives changes the chemical composition of milk in a meaningful way (Kumar and Kumar (2018); Patel et al. (2017); Mirzaeiet al. (2012) and Mahmoud and Ghoneem, 2014)

\section{Effect of dietary inclusion of cumin seed on udder health of dairy cows}

For the study of udder health, we have mainly determined the somatic cell count, milk pH an MCMT in the milks of dairy cows and their results are presented in Table 3 and 4. In the current study, there was no significant ( $p>0.05$ ) change in the $\mathrm{pH}$ value of milk in both the groups, but in the treatment group, milk $\mathrm{pH}$ was numerically higher than the control. 
The blood-milk barrier is damaged in clinical mastitis and sub clinical mastitis (SCM) and mammary epithelial tight junctions become leaky, leading to the escape of blood and extracellular fluid components into the lumen of the alveolus and a decrease in milk secretion rate (Nguyen and Neville, 1998). Blood and extracellular fluid components in inflamed quarters mix with secreted milk (Zhao and Lacasse, 2008) and increase milk $\mathrm{pH}$, with the magnitude of the increase being positively associated with the severity of the inflammatory process (Qayyum et al., 2016). Similar to present experiment results, Preciado et al. (2011) observed that the 12 per cent reduction of milk pH by supplementation of herbal galactogogue in Holstein cows. Similarly, Garg and Singh (2008) and Bharti et al. (2015) also reported significantly higher $(\mathrm{P}<0.05) \mathrm{pH}$ in mastitic milk compared to normal quarter milk. Similar results were also obtained by Kolte et al. (2008) in which they observed that the

Table 3: Effect of dietary inclusion of cumin seed on modified california mastitis test of dairy cows.

\begin{tabular}{lcc}
\hline \multirow{2}{*}{ Fortnights } & $T_{0}$ (control) & $T_{1}$ (treatment) \\
\cline { 2 - 3 } & No. of test (Positive) & \\
\hline Initial & 03 & 02 \\
$1^{\text {st }}$ & 01 & 01 \\
$2^{\text {nd }}$ & 00 & 00 \\
$3^{\text {rd }}$ & 00 & 00 \\
$4^{\text {th }}$ & 01 & 00 \\
$5^{\text {th }}$ & 00 & 00 \\
$6^{\text {th }}$ & 01 & 01 \\
Overall mean\% & 14.29 & 9.52 \\
\hline
\end{tabular}

untreated control group showed non significant increase in $\mathrm{pH}$ throughout the experimental period.

Modified California mastitis test (MCMT) were assessed following $0,1^{\text {st }}, 2^{\text {nd }}, 3^{\text {rd }}, 4^{\text {th }}, 5^{\text {th }}$ and $6^{\text {th }}$ fortnight of experimental period and the data generated are presented in Table (3). Results of modified california mastitis test (MCMT) revealed that the overall mean (\%) of the MCMT positive animals was 14.29 and 9.52 in $T_{0}$ (Control) and $T_{1}$ (Treatment) group, respectively. Similar to these findings, Sharma et al. (2014) reported reduced occurrence of subclinical mastitis in cows with supplementation of poly herbal in dairy cow. Nurdin et al. (2011) reported that the decrease of mastitis by feeding of herbs in dairy cow. Kumar et al. (2011) also revealed reduction of subclinical mastitis by supplementation of shatavari in crossbred cows. Weghmare (2005) also found that 52.38 per cent decrease subclinical mastitis by therapeutic efficacy of autogenous vaccine with herbal drugs in lactating cows.

\section{Effect of dietary cumin seed supplementation on somatic cell count}

In dairy cows, the somatic cell count (SCC) is a useful predictor of subclinical mastitis and therefore, it is an important component of milk in terms of quality, hygiene and mastitis control (Harmon, 1994). The SCC plays a protective role against infection in bovine mammary gland as a normal part of defense mechanism. The SCC below 5 $\mathrm{x} 10^{5} \mathrm{cell} / \mathrm{ml}$ is considered to be normal (Youl and Nicholls, 1987). In the present study the overall mean values of somatic cell count $\left(10^{5}\right)$ were $2.37 \pm 0.05$ and $1.98 \pm 0.09$ in $\mathrm{T}_{0}$ and $\mathrm{T}_{1}$ group, respectively and it lies within the normal physiological range (SCC, 1.91-2.43) in dairy cattle (Youl

Table 4: Effect of dietary cumin seed supplementation on milk somatic cell count and milk pH of dairy cows.

\begin{tabular}{|c|c|c|c|}
\hline Fortnights & $\mathrm{T}_{0}$ (Control) & $\mathrm{T}_{1}$ ( Treatment) & Level of significance \\
\hline \multicolumn{4}{|l|}{ Somatic cell count } \\
\hline Initial & $2.43 \pm 0.14$ & $2.42 \pm 0.14$ & 0.96 \\
\hline $1^{\text {st }}$ & $2.37 \pm 0.11$ & $1.99 \pm 0.13$ & 0.86 \\
\hline $2^{\text {nd }}$ & $2.35 \pm 0.08$ & $1.93 \pm 0.12$ & 0.50 \\
\hline $3^{\text {rd }}$ & $2.28 \pm 0.07$ & $1.82 \pm 0.10$ & 0.36 \\
\hline 4th & $2.43 \pm 0.03$ & $1.80 \pm 0.08^{*}$ & 0.05 \\
\hline $5^{\text {th }}$ & $2.35 \pm 0.05$ & $1.91 \pm 0.05$ & 0.19 \\
\hline $6^{\text {th }}$ & $2.42 \pm 0.03$ & $2.02 \pm 0.05$ & 0.35 \\
\hline Overall mean $\pm S E$ & $2.37 \pm 0.05$ & $1.98 \pm 0.09$ & 0.40 \\
\hline \multicolumn{4}{|l|}{ Milk pH } \\
\hline Initial & $6.90 \pm 0.05$ & $6.84 \pm 0.05$ & 0.67 \\
\hline $1^{\text {st }}$ & $6.79 \pm 0.06$ & $6.57 \pm 0.08$ & 0.62 \\
\hline $2^{\text {nd }}$ & $6.85 \pm 0.06$ & $6.51 \pm 0.06$ & 0.99 \\
\hline $3^{\text {rd }}$ & $6.79 \pm 0.07$ & $6.40 \pm 0.03^{*}$ & 0.03 \\
\hline 4th & $6.69 \pm 0.06$ & $6.35 \pm 0.05$ & 0.22 \\
\hline $5^{\text {th }}$ & $6.91 \pm 0.06$ & $6.61 \pm 0.06$ & 0.79 \\
\hline 6th & $6.73 \pm 0.09$ & $6.55 \pm 0.08$ & 0.43 \\
\hline Overall mean $\pm S E$ & $6.81 \pm 0.02$ & $6.55 \pm 0.02$ & 0.74 \\
\hline
\end{tabular}

${ }^{*}$ shows significance at $5 \%$ level as compared to control group $(\mathrm{P}<0.05)$. 
and Nicholls, 1987). In the present study, the values of SCC were approaching towards lower in the $T_{1}$ group during all fortnights although statistical difference was non- significant ( $P>0.05$ ), it means udder health might be improved due to cumin seed supplementation. Increase of SCC indicated inflammatory reaction and might be due to shift of leucocytes to the udder after entry of infection in the mammary gland and as a protective mechanism against infection (Murcus et al., 1994). Current results corroborated well with the findings of other workers (Sharma et al. 2014; Singh et al. 2019; Kumar et al. (2011); Azadi et al. (2011) and Preciado et al. (2011). In Corroboration, Chandra et al. (2017) also observed that the Somatic cell count (SCC) was significantly $(\mathrm{P}<0.05)$ lower in poly-herbal mixture and butyric acid supplemented groups as compared to control group in Murrah buffaloes.

From the results it can be deduced that the cumin seed (Cuminum cyminum) supplementation improves the milk yield However, it has no effect on chemical composition of milk in dairy cows. Supplementation also improves the health of the udder in the treatment group while, supplementation did not affect the voluntary dry matter intake in dairy cows.

\section{ACKNOWLEDGEMENT}

The authors express thankfulness to the In-charge Ahilyamatagaushala, Indore and the Dean, College of Veterinary Sciences and Animal Husbandry, Mhow for providing necessary facilities to carry out the experiment.

\section{REFERENCES}

A.O.A.C. (2005). Official Methods of Analysis. In: Proceedings of $17^{\text {th }}$ Edn. Association of Official Analytical Chemists, Washington, D.C. USA.

Azadi, H.G., Farzaneh, N., Baghestani, Z., Mohamadi, A. and Shahri, S.A.M. (2011). Effect of intramammary injection of nigella sativa on somatic cell count and staphylococcus aureus count in Holstein cows with $S$. aureussubclinical mastitis. American Journal of Animal and Veterinary Sciences. 6(1): 31-34.

Bharti, P., Bhakat, C., Ghosh, M.K., Dutta, T.K. and Das, R. (2015). Relationship among intramammary infection and raw milk parameters in Jersey crossbred Cows under hot-humid climate. Journal of Animal Research. 5(2): 317-320.

Bhatt, N., Singh, M. and Ali, A. (2009). Effect of feeding herbal preparations on milk yield and rumen parameters in lactating crossbred cows. International Journal of Agriculture and Biology. 11: 721-726.

Chandra, S., Oberoi, P.S., Bhakat, M., Yogi, R.K., Yadav, A., Singh, P.K. and Kumar, A. (2017). Effect of dietary supplementation of poly-herbal mixture and butyric acid on milk production, milk quality and somatic cell counts of postpartum Murrah buffaloes. Indian Journal of Animal Research. 51(5): 892-895.

Dang, A.K. and Anand, S.K. (2007). Effect of milking systems on the milk somatic cell counts and composition. Livestock Research and Rural Development. 19 (6):1-9.
Durrani, F.R., Chand, N., Zaka, K., Sultan, A., Khattak, F.M. and Durrani, Z. (2007). Effect of different levels of feed added black seed (Nigella sativa L.) on the performance of broiler chicks. Pakistan Journal of Biological Science. 22(10): 4164-4167.

Galbat, S.A., El-Shemy, A., Madpoli, A.M., Maghraby, O.M.A.L. and El-Mossalami, E.I. (2014). Effects of some medicinal plants mixture on milk performance and blood components of Egyptian dairy Goats. Middle East Journal of Applied Sciences. 4(4): 942-948.

Garg, A. and Singh, M. (2008). Risk assessment factors for detection of sub-clinical mastitis in crossbred cattle. Indian Journal of Dairy Science. 61(6): 465-467.

Gautam, K.L., Bishist, R., Dutt, B. and Namgial, J. (2019). Effect of Polyherbal supplementation on milk performance of crossbred cows. International Journal of Livestock Research. 9(7): 204-210.

Ghafaria, M., Shahrakia, A.D.F., Nasrollahib, S.M., Amini, H.R. and Beauchemin, K.A. (2015). Cumin seed improves nutrient intake and milk production by dairy cows. Journal of Animal Feed Science and Technology. 210: 276-280.

Goswami, D.R., Islam, R., Hasan, M.M., Sarkar S., Aziz, F.B., Pervez, M.M.M. and Salauddin, M. (2018). Comparative efficacy of black cumin and domperidone therapy on milk yield and fat percentage of indigenous cow. Asian-Australasian Journal of Bioscience and Biotechnology. 3(1): 67-71.

Harmon, R. (1994). Physiology of mastitis and factors affecting somatic cell counts. Journal of Dairy Science. 77: 2103-2112.

Hashemian, N., GhasemiPirbalouti, A., Hashemi, M., Golparvar, A. and Hamedi, B. (2013). Diversity in chemical composition and antibacterial activity of essential oils of cumin (Cuminum cyminum L.) diverse from northeast of Iran. Australian Journal of Crop Science. 7: 1752-1760.

ICAR. 2013. Nutrient Requirements of Cattle and Buffalo. Indian Council of Agricultural Research, New Delhi, India.

Kolte, A.Y. ,Waghmare, S.P., Mode, S.G. and Handa, A. (2008). Efficacy of indigenous herbal preparation on altered milk $\mathrm{pH}$, somatic cell count and electrolyte profile in subclinical mastitis in cows. Veterinary World. 1(8): 239-240.

Kumar, S. and Kumar, B. (2018). Comparative assessment of different herbal galactogogue preparations on milk production and economics of lactating crossbred cows. Journal of Pharmacognosy and Phytochemistry. 7(5): 2508-2512.

Kumar, S., Mehla, R. K., Sirohi, S. K., Dang, A.K. and Kimothi, S.P. (2011). Effect of herbal feed supplement (Shatavari) on incidence of mastitis in crossbred cows. Indian Journal of Animal Sciences. 82(6): 586-590.

Mahmoud, A.E.M. and Ghoneem, W.M.A. (2014). Effect of partial substitution of dietary protein by nigella sativa meal and sesame seed meal on performance of Egyptian lactating buffaloes. Asian journal of animal and veterinary advances. 9(8): 489-498.

Miri, V.H., Tyagi, A.K., Ebrahimi, S.H. and Mohini, M. (2013). Effect of cumin (Cuminum cyminum) seed extract on milk fatty acid profile and methaneemission in lactating goat. Journal of Small Ruminant Research. 113: 66-72. 
Mirzaei, F. (2012). Effect of herbal feed additives on performance parameters of ruminants and especially on dairy goat: $\mathrm{A}$ Review. International Journal for Agro Veterinary and Medical Sciences. 6: 307-331.

Moghaddam, M., Miran, S.N.K., Pirbalouti, A.G., Mehdizadeh, L. and Ghaderi, Y. (2015). Variation in essential oil composition and antioxidant activity of cumin (Cuminum cyminum L.) fruits during stages of maturity. Industrial Crops and Products. 70: 163-169.

Morsy, T.A., Kholif, A.E., Matloup, O.H., Elella, A.A., Anele, U.Y. and Caton, J.S. (2018). Mustard and cumin seeds improve feed utilisation, milk productionand milk fatty acids of Damascus goats. Journal of Dairy Research. 85(2): 142-151.

Murcus, E., Kehril, U.R. and Dale, E.S. (1994). Factors affecting milk somatic cells and their role in health of the bovine mammary gland. Journal of Dairy Science. 77: 619.

Muthamma, M.K.S., Hemang, D., Purnima, K.T. and Prakash, V. (2008). Enhancement of digestive enzymatic activity by cumin (Cuminum cyminum L.) and role of spent cumin as a bionutrient. Food Chemistry. 110: 678-683.

Nguyen, D.D. and Neville, M.C. (1998). Tight Junction Regulation in the Mammary Gland. Journal of Mammary Gland Biology and Neoplasia. 3(3): 233-246.

Nurdin, E., Amelia, T. and Makin, M. (2011). The effects of herbs on milk yield and milk quality of mastitis dairy cow. Journal of Indonesian Tropical Animal Agriculture. 36(2): 104-108.

Patel, V. K., Chauhan, H.D., Pawar, M.M., Srivastava, A.K. and Prajapati, K.B. (2017). Effect of herbal galactogogue supplementation on production performance of lactating Kankrej Cows. International Journal of Current Microbiology and Applied Sciences. 6(12): 2093-2098.

Preciado, A.T., Hernandez, J.R.O., Carranza, A.C., Mora, V.C.D.I. and Chaves, G.R. (2011). Use of an herbal galactogogue on milk quality and yield. Asian Journal of Animal and Veterinary Advances. 6(3): 297-300.

Qayyum, A., Khan, J.A., Hussain1, R., Khan, A., Avais, M., Ahmad, N. and Hassa, M.F. (2016). Molecular characterization of staphylococcus aureus isolates recovered from natural cases of subclinical mastitis in cholistani cattle and their antibacterial susceptibility. Pakistan Journal of Agricultural Sciences. 53(4): 1-6.
Ramesh P.T., Mithra S.K., Syryanarayan T. and Sachan, A. (2000). Evaluation of galactin, A herbal galactagogue preparation in dairy cows. The Veterinarian. (24): 15.

Sastry, G. A. (1978). Clinical Veterinary Medicine Pathology. CBS Publishers and Distributors Delhi., $2^{\text {nd }}$ edn.

Sastry, N.S.R., Thomas, C.K. and Singh, R.A. (1982). Farm animal management and Poultry production, $2^{\text {nd }}$ ed. Vikas Publishing House Pvt. Ltd., New Delhi.

Sastry, N.S.R., Thomas, C.K. and Singh, R.A. (1982). Farm Animal management and Poultry Production, Vikas Publishing House Pvt. Ltd., New Delhi. $2^{\text {nd }}$ edn.

Sharma, A., Prasad, S., Singh, Y. and Bishisth, R. (2014). Effect of polyherbal preparation supplementation on immunity and udder health of periparturient Karan-Fries crossbred dairy cows. Journal of Applied Animal Research. 42 (2): 217-221.

Singh, K., Mishra, K.K., Shrivastav, N., Mishra, S.K., Singh, A.K., Jha, A.K., Tiwari, N. and Ranjan, R. (2019). Therapeutic efficacy of indigenous polyherbal formulation on milk ph, somatic cell count and electrical resistance profile in healthy and subclinical mastitic dairy cows. International Journal of Current Microbiology and Applied Sciences. 8(10): 703-710.

Tassoul, M.D. and Shaver, R.D. (2009). Effect of a mixture of supplemental dietary plant essential oils on performance of periparturient and early lactation dairy cows. Journal of Dairy Science. 92(4): 1734-40.

Van soest, P.J., Robertson, J.B. and Lewis, B.A. (1991). Symposium: Carbohydrate methodology, metabolism and nutritional implications in dairy cattle. Journal of Dairy Science. 74(10): 3583-3597.

Weghmarer, S.P., Daimi, S.G.R., Ali, S.Z., Maral, U.J. and Ali, S.S. (2005). Therapeutic Efficacy of autogenous vaccine with herbal drugs against subclinical mastitis with reference to immunological study. Research Journal of Dr. Panjabrao Deshmukh Krishi Vidyapeeth Akola. 29(1): 111-114.

Youl, B.S. and Nicholls, T.J. (1987). The relationship between somatic cell count and lactation yield of dairy cows. Australian Journal of Dairy Technology. 42: 68-70.

Zhao, X. and Lacasse, P. (2008). Mammary tissue damage during bovine mastitis causes and control. Journal of Animal Science. 86(13): 57-65. 